\title{
Konstruksi Model Matematika Pola Curah Hujan Menggunakan Artificial Neural Network (ANN) dengan Metode Backpropagation
}

\author{
Habibi Ratu Perwira Negara', Irzani², Ripai ${ }^{3}$ \\ 1Pendidikan Matematika, Universitas Islam Negeri Mataram, habibiperwira@uinmataram.ac.id \\ 2Pendidikan Matematika, Universitas Islam Negeri Mataram, irzani@uinmataram.ac.id \\ ${ }^{3}$ Balai Informasi Sumber Daya Air DPU NTB, ripai.nasir@gmail.com
}

\begin{tabular}{l} 
INFO ARTIKEL \\
\hline Riwayat Artikel: \\
Diterima: 05-03-2018 \\
Disetujui: 10-04-2018 \\
\hline
\end{tabular}

Kata Kunci:

Artificial Neural Network, Backpropagation,

Curha Hujan

\section{A. LATAR BELAKANG}

Indonesia adalah negara agraris atau negara pertanian, di mana mayoritas penduduknya bermata pencaharian sebagai petani. Kebanyakan penduduk negeri ini bercocok tanam dan mengelola tanah sebagai sumber kehidupan, sifat-sifat iklim seperti suhu, curah hujan, dan musim sangat berpengaruh terhadap kehidupannya, sehingga faktor-faktor iklim seperti cuaca dan iklim benar-benar dipertimbangkan dalam mengembangkan pertanian.

Kondisi suhu, curah hujan, dan pola musim sangat menentukan kecocokan dan optimalisasi pembudidayaan tanaman pertanian. Misalnya, padi sangat cocok dibudidayakan di daerah yang bersuhu udara panas dengan curah hujan yang cukup tinggi. Tanaman hortikultura, seperti sayur-sayuran dan buah- buahan cocok dibudidayakan di daerah sedang sampai sejuk dengan intensitas curah hujan tidak setinggi pada tanaman padi.

Pengaruh perubahan iklim global khususnya terhadap sektor pertanian di Indonesia sudah terasa dan menjadi kenyataan. Perubahan ini diindikasikan antara lain oleh adanya bencana banjir, kekeringan (musim kemarau yang panjang) dan bergesernya musim hujan. Dalam beberapa tahun terakhir ini pergeseran musim hujan menyebabkan bergesernya musim tanam dan panen komoditi pangan (padi, palawija, dan sayuran). Sedangkan banjir dan kekeringan menyebabkan gagal tanam, gagal panen, dan bahkan menyebabkan puso.

Provinsi Nusa Tenggara Barat (NTB) adalah salah satu provinsi penyangga pangan nasional terutama beras yang sangat diharapkan dapat menyumbangkan produksi padi lebih dari 70 ribu ton Gabah Kering Giling 
(GKG) atau sama dengan 40 ribu ton beras tiap tahun [3]. Perubahan iklim di suatu daerah diindikasikan pula oleh adanya variasi iklim musiman (seasonal variability). Variasi iklim musiman di Pulau Lombok Nusa Tenggara Barat ditandai oleh terjadinya kemarau panjang, musim hujan yang tidak menentu, dan jangka waktunya relatif singkat, sehingga sering menyebabkan gagal panen dan bahkan gagal tanam untuk tanaman pangan seperti padi, palawija, dan sayuran. Dengan kata lain, variasi iklim musiman dapat dikatakan sebagai salah satu penyebab utama menurunnya produksi pertanian dalam arti luas terutama produktivitas tanaman pangan, perkebunan, kehutanan dan bahkan peternakan.

Usaha tani padi secara intensif di Pulau Lombok NTB khususnya di wilayah Lombok Tengah bagian Selatan dan Lombok Timur bagian Selatan dilaksanakan pada berbagai jenis lahan pertanian, yakni lahan kering dan lahan sawah (lahan basah). Lahan kering (upland, dry land atau unirrigated land) merupakan kawasan lahan yang didayagunakan tanpa penggenangan air secara permanen maupun musiman, baik oleh air yang bersumber dari air hujan maupun irigasi [3]. Lahan pertanian di Lombok Tengah bagian Selatan dan Lombok Timur bagian Selatan terdiri atas lahan kering berupa ladang dan sawah. Sawah terdiri dari sawah beririgasi teknis, yakni sawah yang selalu memperoleh air sepanjang tahun, sawah beririgasi setengah teknis, yakni sawah yang kekurangan air di musim kemarau, dan lahan sawah tadah hujan (rainfed) yakni sawah yang irigasinya tergantung sepenuhnya pada hujan. Jika terjadi kekeringan karena kemarau panjang maka tanaman padi yang ditanam di daerah lahan sawah tadah hujan akan mengalami cekaman air yang paling parah, sehingga produksinya berbeda dengan produksi tanaman di daerah beririgasi.

Berkaitan dengan curah hujan yang mempengaruhi produksi padi, baik di daerah sawah beririgasi maupun di daerah tadah hujan, maka perlu ada pengaturan pola tanam dan jadwal tanam yang tepat agar air hujan dapat dimanfaatkan oleh tanaman padi secara efektif, mengingat khususnya untuk wilayah Lombok Tengah bagian Selatan dan Lombok Timur bagian Selatan, masyarakat memiliki pola tanam pada musim penghujan menanam padi sedangkan pada musim kering menanam tembakau. Namun hal tersebut belum dapat ditentukan dikarenakan pola curah hujan yang tak menentu.

Melihat keadaan tersebut, sehingga perlu dilakukan kajian tentang pola curah hujan, mengingat bahwa curah hujan merupakan faktor penting pada sektor pertanian. Selama ini banyak prediksi curah hujan dilakukan secara intuitif atau dengan menggunakan metode-metode statistik. Banyak metode untuk melakukan prediksi tersebut, misalnya metode Smoothing, Box-Jenkins, ekonometri, regresi, metode masukan-keluaran dan sebagainya. Pemilihan metode-metode tersebut yang digunakan pada perhitungan untuk meramalkan suatu hal tertentu tergantung pada berbagai aspek yang mempengaruhi yaitu aspek waktu, pola data, tipe model sistem yang diamati, tingkat keakuratan forecast atau ramalan yang diinginkan dan sebagainya. Karena itulah akan muncul suatu masalah apabila pengamatan atau pengujian dilakukan pada suatu sistem dinamis yang memiliki sistem pola data dengan formulasi yang selalu berubah-ubah atau dengan kata lain sistem yang memiliki tingkat kesulitan yang tinggi untuk dibuatkan formulasi modelnya pada suatu kurun waktu tertentu seperti halnya sistem prediksi curah hujan.

Seiring dengan kemajuan di bidang perangkat lunak, maka berbagai model prediksi juga mengalami kemajuan yang cukup pesat. Ditambah dengan semakin meningkatnya kebutuhan terhadap ketersediaan data dan informasi aktual beberapa waktu ke depan, sehingga kondisi ini semakin mendorong berkembangnya berbagai model prediksi. Selain teknik menyusun model prediksi curah hujan yang disebutkan diatas, yang sudah umum digunakan, misalnya Regresi, ARIMA, Analisis Fourier, dan Analisis Kalman Filter. Teknik-teknik tersebut hanya terkonsentrasikan pada aspek analisis waktu atau analisis ruang saja. "Lee et al (1998) serta Halide dan Ridd (2000) memanfaatkan teknik analisis jaringan Saraf (neural network analisis, NNA) pada bidang hidrologi. Teknik ini mampu menggabungkan aspek analisis waktu dan ruang secara simultan [1].

Dengan menggunakan teknologi di bidang Artificial Intellegence yaitu teknologi jaringan saraf tiruan maka identifikasi pola data dari sistem prediksi curah hujan dapat dilakukan dengan metode pendekatan pembelajaran atau pelatihan yaitu untuk menentukan bobot penghubung antar simpul yang optimum. Keunggulan utama artificial neural network adalah kemampuan komputasi yang paralel dengan cara belajar dari pola-pola yang diajarkan. Berdasarkan kemampuan belajar yang dimilikinya, maka artificial neural network dapat dilatih untuk mempelajari dan menganalisa pola data masa lalu dan berusaha mencari suatu formula atau fungsi yang akan menghubungkan pola data masa lalu dengan keluaran yang diinginkan pada saat ini.

Dengan adanya berbagai macam arsitektur jaringan dan pelatihan yang ada pada artificial neural network maka dapat dipilih arsitektur jaringan dan pelatihan yang digunakan agar artificial neural network dapat mempelajari dan menganalisa pola data masa lalu lebih tepat sehingga diperoleh keluaran yang lebih akurat (dengan kesalahan atau error yang minimum).

Berdasarkan keadaan cuaca yang tidak menentu, yang mengakibatkan pergeseran pola tanam di daerah Lombok Tengah bagian Selatan dan Lombok Timur bagian Selatan, maka perlu dilakukan penelitian untuk mengetahui pola curah hujan dengan penerapan Artificial Neural Network (ANN) dalam mengkonstruksi model matematika pola curah hujan di daerah Lombok Tengah bagian Selatan dan Lombok Timur bagian Selatan menggunakan metode Backpropagation. 


\section{B. METODE PENELITIAN}

1. Rancangan Penelitian

Dalam rencana penelitian memuat strategi dan struktur penelitian yang diatur untuk menjawab masalah penelitian.

Berikut adalah skema rancangan penelitian yang akan dilaksanakan :

tersebut, dilakukan validasi data. Pengujian validasi bertujuan untuk mengetahui sampel data yang digunakan dapat dijamin mewakili populasi. Data yang telah divalidasi, selanjutnya dicari rata-rata curah hujan dari ke-5 pos sebagai data curah hujan di Lombok Tengah bagian Selatan. Langkah selanjutnya di buat model pola curah hujan dengan

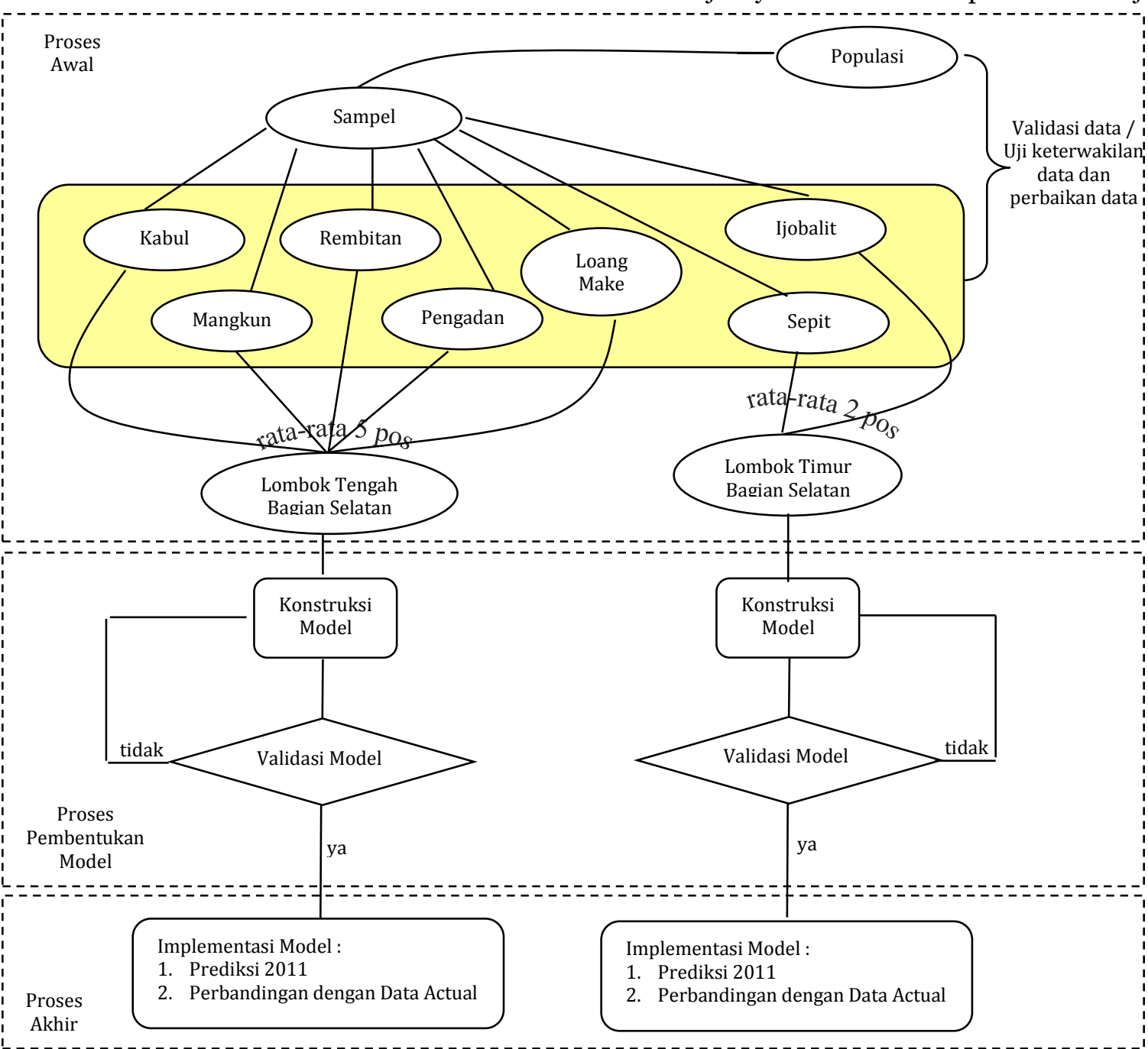

Gambar 1. Skema Rancangan penelitiBß̈ckpropagation menggunakan MATLAB.

Populasi dalam penelitian ini adalah curah hujan Lombok Tengah bagian Selatan dan Lombok Timur bagian Selatan. Karena tidak mungkin dapat dilakukan pengukuran curah hujan di seluruh wilayah Lombok Tengah bagian Selatan dan Lombok Timur bagian Selatan, maka dibutuhkan data sampel pola curah hujan yang dapat menggambarkan curah hujan di Lombok Tengah bagian Selatan dan Lombok Timur bagian Selatan. Balai Informasi Sumber Daya Air (BISDA) Pekerjaan Umum NTB, telah menempatkan 5 titik sampel (pos) pola curah hujan di daerah Lombok Tengah bagian Selatan yang terrasionalisasi yaitu pos curah hujan Kabul, Mangkung, Rembitan, Pengadang, dan Loang Make. Untuk daerah Lombok Timur bagian Selatan terdapat 2 titik sampel (pos) pola curah hujan, yaitu pos curah hujan Sepit dan Ijobalit. Dari data yang diperoleh pada tiap pos pengamatan curah hujan
Setelah diperoleh model pola curah hujan, selanjutnya dikonstruksi perkiraan pola curah hujan untuk tahun 2011. Dari hasil yang diperoleh dilakukan perbandingan terhadap data Observasi tahun 2011, untuk mengatahui keakruatan hasil prediksi yang diperoleh. Perbandingan yang dilakukan terhadap data beberapa bulan yang sudah dilakukan perhitungan.

Untuk pola curah hujan di daerah Lombok Timur bagian Selatan, dicari rata-rata curah hujan dari ke-2 pos sebagai data curah hujan di Lombok Timur bagian Selatan. Setelah diperoleh model dengan data rataan pola curah hujan di daerah Lombok Timur bagian Selatan, selanjutnya dilakukan prediksi untuk curah hujan pada tahun 2011. Hasil yang diperoleh dibandingkan dengan data Observasi tahun 2011, untuk mengetahui akurasinya. 
2. Data dan Metode Pengumpulan Data

Data yang digunakan berupa data setengah bulanan yang dicatat dari tahun 1973 sampai tahun 2010 untuk daerah Lombok Tengah bagian Selatan dan data dari tahun 1974 sampai tahun 2010 untuk daerah Lombok Timur bagian Selatan. Metode yang digunakan adalah metode dokumentasi, data diperoleh dari dari BISDA Dinas Pekerjaan Umum NTB.

\section{Validasi Data}

Data tersebut selanjutnya disebut data hidrologi. Data hidrologi adalah kumpulan keterangan atau fakta mengenai fenomena hidrologi. Fenomena hidrologi seperti besarnya curah hujan, temperatur, penguapan, lama penyinaran matahari, kecepatan angin, debit sungai, tinggi muka air sungai, kecepatan aliran, konsentrasi sedimen sungai akan selalu berubah menurut waktu[2].

Data hidrologi yang diukur atau nilai yang diperoleh sudah barang tentu mengandung kesalahan (error). Dan hal tersebut berpengaruh terhadap analisis hidrologi. Sumber error (kesalahan) data setidaknya mencakup asumsi yang terkandung dalam alat perhitungan, kualitas data pengukuran atau observasi. Dari aspek data, error dapat muncul dari proses perekaman data di lapangan maupun pada transformasi data sehingga, sebelum memanfaatkan data untuk berbagai kepentingan hendaknya melalui proses uji validasi data.

Data dikatakan valid jika memenuhi kriteria bahwa data itu berada dalam range, tidak bertrend, homogen dan keacakan. Jika data tidak memenuhi kritria tersebut, maka diperlukan langkah penyesuaian [2]. Demikian pula jika terjadi missing data maka diperlukan upaya pengisian data.

Metode yang digunakan untuk penyaringan data mencakup :

a. Log Person III (uji range - konsistensi)

$\log X_{a b}=\log X \pm S . k$

dimana :

$X_{\mathrm{ab}}=$ nilai batas atas $\left(X_{\mathrm{a}}\right)$ dan batas bawah $\left(X_{\mathrm{b}}\right)$ yang diperkenankan

$X$ = rataan data

$\mathrm{S}=$ deviasi standar

$\mathrm{k}=$ koefisien $\log$ Pearson III (fungsi dari koefisien kemencengan dan batas kepercayaan) [2].

\section{b. Peringkat Spearman (uji trend)}

"Deret berkala yang nilainya menunjukkan gerakan yang berjangka pajang dan mempunyai kecenderungan menuju kesatu arah, arah menaik atau menurun disebut dengan pola atau trend (trend) [4]. umumnya meliputi gerakan yang lamanya lebih dari 10 tahun. Time series yang dataya kurang dari 10 tahun kadang-kadang sulit untuk mengikuti gerakan dari suatu trend. Hasilnya dapat meragukan, karena gerakan yang diperoleh hanya mungkin menunjukkan suatu sikli dari suatu trend. Sikli adalah gerakan yang tidak teratur dari suatu trend [4].

Apabila dalam deret berkala menunjukkan adanya trend maka datanya tidak disarankan untuk digunakan dalam beberapa analisis hidrologi, misalnya analisis peluang dan simulasi. Apabila deret berkala itu menunjukkan adanya trend, maka analisis hidrologi harus mengikuti garis trend yang dihasilkan dengan menggunakan analisis regresi.

Ketidakadaan trend dapat diuji dengan banyak cara. Secara visual dengan cara menggambarkan deret berkala dalam kertas grafik aritmatik, sedangan dengan metode statistik salah satu cara yang digunakan untuk menguji ketidakadaan trend adalah dengan korelasi perigkat metode spearman. Dengan rumus sebagai berikut,

$K P=1-\frac{6 \sum_{i=1}^{n}(d t)^{2}}{n^{3}-n}$

$t=K P\left[\frac{n-2}{1-K P^{2}}\right]^{\frac{1}{2}}$

Keterangan :

$\mathrm{KP}=$ koefisien korelasi peringakat dari spearman

$\mathrm{n}=$ jumlah data

$\mathrm{dt}=\mathrm{Rt}-\mathrm{Tt}$

$\mathrm{Tt}=$ peringkat dari waktu

Rt $=$ peringkat dari variabel hidrologi dalam deret berkala

$\mathrm{t}$ = nilai pola $\mathrm{t}$, pada derajat kebebesan (n-2) untuk derajat kepercayaan tertentu (umumnya $5 \%)$ [4]

c. Uji $t$ (uji statsioner - homogenitas)

Setelah dilakukan pengujian ketidakadaan trend. Apabila time series tersebut tidak menunjukkan adanya trend, maka sebelumnya data time series digunakan untuk analisis lanjutan, data harus dilakukan uji stasioner. Uji statsioner dimaksudkan untuk menguji kestabilan nilai varian data rata-rata time series.

Pengujian nilai varian dari time series dapat dilakukan dengan uji-Fisher (Uji-F). Data Time series dibagi menjadi dua kelompok atau lebih, setiap dua kelompok diuji menggunakan Uji-F. Apabila hasil pengujian ternyata hipotesis nol ditolak, berarti nilai varian tidak stabil. Deret yang nilai variannya tidak homogen berarti deret tersebut tidak stasioner, dan tidak perlu melakukan pengujian lanjutan. Akan tetapi apabila hipotesis nol untuk nilai varian tersebut menunjukkan stasioner, maka pengujian selanjutnya adalah kestabilan nilai rata-ratanya. Untuk rata-rata time series bila 
datanya dianggap sebuah populasi maka dapat dilakukan pengujian dengan menggunakan ujistudent (Uji-t). Seperti dalam pengujian kestabilan nilai varian, maka dalam pengujian nilai rata-rata, data time series dibagi menjadi dua kelompok atau lebih. Setiap pasangan 2 kelompok diuji, apabila dalam pengujian ternyata hipotesis nol ditolak, berarti nilai rata-rata setiap dua kelompok tidak stasioner pada derajat kepercayaan tertentu. Berikut rumus yang digunakan :

Uji Kestabilan varian

$$
F=\frac{n_{1} S_{1}{ }^{2}\left(n_{2}-1\right)}{n_{2} S_{2}{ }^{2}\left(n_{1}-1\right)}
$$

Uji Kestabilan nilai rata-rata

$$
\begin{aligned}
& t=\frac{\bar{X} 1-\bar{X}_{2}}{\sigma\left(\frac{1}{n_{1}}+\frac{1}{n_{2}}\right)^{\frac{1}{2}}} \\
& \sigma=\left(\frac{n_{1} S_{1}^{2}+n_{2} S_{2}^{2}}{n_{1}+n_{2}-2}\right)^{\frac{1}{2}}
\end{aligned}
$$

d. Koefisen Serial Spearman (uji persistensi - acak) Anggapan bahwa data berasal dari sampel acak harus diuji, yang umumnya merupakan persyaratan dalam analisis distribusi peluang. Persistensi (Persistence) adalah ketidaktergantungan dari setiap nilai dalam time seriesn [4] untuk melaksanakan pengujian persistensi harus dihitung besarnya koefisien korelasi serial. Salah satunya metode untuk menentukan koefisen korelasi serial adalah dengan metode Spearman, yang dirumuskan sebagai berikut

$$
\begin{aligned}
& K S=1-\frac{6 \sum_{i=1}^{m}(d i)^{2}}{m^{3}-m} \\
& t=K S\left[\frac{m-2}{1-K S^{2}}\right]^{\frac{1}{2}}
\end{aligned}
$$

Keterangan :

$K S=$ koefisien korelasi serial

$m=\mathrm{N}-1$

$\mathrm{N}=$ jumlah data

$d i=$ perbedaan nilai antara peringkat data $X_{i}$ dan ke $X_{i}+1$

$\mathrm{t}=$ nilai pola $\mathrm{t}$, pada derajat kebebesan $(\mathrm{m}-2)$ dan derajat kepercayaan tertentu (umumnya $5 \%$ ditolak, atau 95\% diterima) [4].

sedangkan proses yang digunakan untuk membangkitkan data time series buatan atas dasar perambatan waktu tahunan adalah proses Markov. Proses Markov merupakan suatu proses dimana setiap peristiwa hanya tergantung pada kejadian yang mendahuluinya. Penggunaan proses Markov mempunyai arti bahwa tiap nilai dalam rangkaian deret berkala buatan tergantung secara langsung dengan nilai yang terjadi sebelumnya. Rangkaian data time series dengan pertambahan waktu bulanan tidak dapat dipandang sebagai variabel bebas, Misalkan curah hujan bulanan ini, besarnya sangat tergantung dari curah hujan bulan yang lalu, bahkan mungkin beberapa bulan yang sebelumnya, oleh karena itu untuk membangkitkan data time series buatan data bulanan dapat digunakan proses Markov. Metode Rantai Markov ini membutuhkan bilangan random yang disesuaikan dan paremeter statistic tertentu [4]. Menggunakan proses Markov adalah menggunakan model auto-regresif tahunan. Model yang paling sederhana adalah Markov-Chain, yang dapat dirumuskan sebagai berikut.

$\mathrm{X}_{\mathrm{i}}=\Gamma\left(\mathrm{X}_{\mathrm{i}-1}\right)+(1-\Gamma) \overline{\mathrm{X}}+(\mathrm{S})(\mathrm{t})\left(1-\Gamma^{2}\right)^{\frac{1}{2}}$

Keterangan :

$\mathrm{X}_{\mathrm{i}}=$ data tahunan pada tahun ke $\mathrm{t}$

$\mathrm{Xi}-1=$ data tahunan pada tahun ke $\mathrm{t}-1$

$\overline{\mathrm{X}}=$ debit rata-rata tahunan dari pengamatan

$\mathrm{S}=$ deviasi standar dari oengamatan

$\Gamma=$ koefisien Marko - Chain, nilai berkisar anatar $0.20-0.30$,umumnya digunakan nila 0.25 .

$\mathrm{t}=$ variat acak dari pola normal dangan rata-rata $=0$ dan deviasi standar $=1,0$ [4].

Apabila $\overline{\mathrm{X}}, \mathrm{S}$ dan $\Gamma$ telah ditetapkan maka membangkitakan deret berkala buatan untuk $n$ tahun dapat dilakukan.

\section{Parameter Penelitian}

Parameter penelitian yang dimaksud adalah satuan yang digunakan untuk meyatakan bahwa model yang digunakan dapat diterima dengan toleransi kesalahan tertentu. Dalam penelitian ini, Konstruksi model matematika dinyatakan valid apabila menemukan MSE (Mean Score Error) yaitu $10^{-4}$

\section{HASIL DAN PEMBAHASAN}

\section{Data Penelitian}

Data penelitian diperoleh dari BISDA, yaitu data hujan setengah bulan. Untuk daerah Lombok Tengan Bagian Selatan, data hujan setengah bulan yang digunakan dari tahun 1973 sampai tahun 2010, sedangkan daerah Lombok Timur bagian Selatan dari tahun 1974 sampai tahun 2010. Sampel dalam penelitian ini adalah pos-pos pengamatan curah hujan yang telah ditentukan oleh BISDA. Dimana, pos-pos tersebut dapat menggambarkan keadaan pola curah hujan di daerah Lombok Tengah bagian Selatan dan Lombok Timur bagian Selatan. Pos-pos pengamatan curah hujan yang terdapat di daerah Lombok Tengah bagian Selatan ada 5 pos pengamatan. Sedangkan Pos-pos pengamatan curah 
hujan yang terdapat di Lombok Timur bagian Selatan terdapat 2 pos pengamatan. Data yang telah divalidasi, selanjutnya dicari nilai rata-rata dari ke 5 pos pengamatan dan nilai rata-rata dari ke 2 pos pengamatan. Berikut grafik pola data rata-rata ke 5 pos pengamatan di Lombok Tengah bagian Selatan diperlihatkan pada gambar 1 dan grafik data ratarata ke 2 pos pengamatan di Lombok Timur bagian Selatan diperlihatkan pada gambar 2.

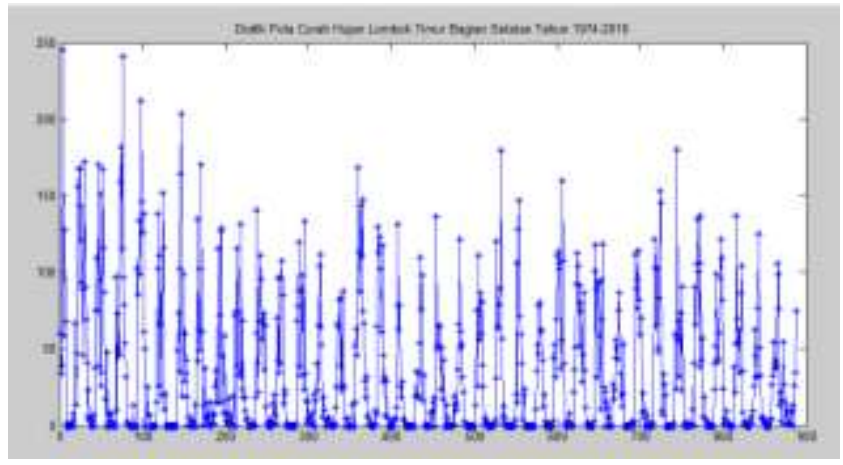

Gambar 2. Grafik Time Series Pola Curah Hujan Setengah Bulan di Daerah Lombok Tengah Bagian Selatan Tahun 1973

Dari nilai rata-rata 5 pos pegamatan dan nilai rata-rata 2 pos pengamatan, selanjutnya dinormalisasi dan digunakan sebagai data penelitian. Data penelitian yang diperoleh selajutnya digunakan sebagai data pembelajaran. Untuk data dari 5 pos pengamatan diperoleh sebanyak 912 data. Data yang diperoleh, dibuat pola pembelajaran, sehingga diperoleh 888 pola. Dari 888 pola yang diperoleh sebanyak 21.312 data digunakan sebagai data training, dan sebanyak 888 data sebagai data target. Sedangkan sebanyak 888 data diperoleh dari 2 pos pengamatan, data dibuat pola pembelajaran. Sehingga diperoleh 864 pola. Sebanyak 20.736 data digunakan sebagai data training, dan sebanyak 864 data sebagai data target.

\section{Kontruksi Model}

Sebelum penentuan model matematika, yang terpenting adalah pemilihan arsitektur jaringan yang terbaik. Arsitektur yang digunakan adalah jaringan backpropagation dengan 2 hidden layer (lapisan tersembunyi). Fungsi Aktivasi yang digunakan pada layer input, hidden dan output adalah logsig. Sedangkan pola pembelajaran yang digunakan adalah Resilent Backpropagation (trainrp). Pada proses penentuan arsitektur ANN backpropagation dilakukan trial and error untuk mendapatkan kinerja ANN yang optimum dengan parameter pemilihan adalah diemensi jaringan (jumlah neuron pada layer input dan hidden layer). Parameter pemilihan arsitektur dilihat dari korelasi kecocokan data pembelajaran dengan target (R), jumlah epoch pembelajaran yang rendah dan MSE terkecil. Berikut adalah tabel arsitektur yang dilakukan trial and error, selanjutnya dari arsitektur-arsitektur tersebut dipilih arsitektur yang terbaik.

TABEL 1.

ARSITEKTUR JARINGAN YANG DILAKUKAN TRIAL AND ERROR

\begin{tabular}{|c|c|c|c|c|c|}
\hline $\begin{array}{c}\text { No } \\
\text {. }\end{array}$ & Arsitektur & $\begin{array}{c}\text { Laye } \\
\mathbf{r} \\
\text { Inpu } \\
\mathbf{t}\end{array}$ & $\begin{array}{c}\text { Layer } \\
\text { hidden } 1\end{array}$ & $\begin{array}{c}\text { Layer } \\
\text { hidden } \\
2\end{array}$ & $\begin{array}{c}\text { Outpu } \\
t\end{array}$ \\
\hline 1. & Arsitektur I & 3 & 4 & 4 & 1 \\
\hline 2. & Arsitektur II & 12 & 24 & 12 & 1 \\
\hline 3. & $\begin{array}{l}\text { Arsitektur } \\
\text { III }\end{array}$ & 140 & 26 & 50 & 1 \\
\hline 4. & $\begin{array}{l}\text { Arsitektur } \\
\text { IV }\end{array}$ & 363 & 54 & 24 & 1 \\
\hline 5. & Arsitektur V & 120 & 240 & 12 & 1 \\
\hline
\end{tabular}

Berikut parameter komputasi yang digunakan pada tiap arsitektur.

TABEL 2.

PARAMETER KOMPUTASI YANG DIGUNAKAN

\begin{tabular}{c|lc}
\hline No. & \multicolumn{1}{c}{ Parameter } & Nilai \\
\hline 1 & Maksimum Epoh & 5000 \\
2. & Kinerja Tujuan / Toleransi & $10^{-4}$ \\
& Galat & \\
3. & Maksimum Kenaikan Kinerja & 1.04 \\
4. & Learnig Rate & 0.01 \\
5. & Rasio Kenaikan Learning Rate & 1.05 \\
6. & Rasio Menurunkan Learning & 0.7 \\
& Rate & \\
7. & Momentum & 0.9 \\
8. & Fungsi Aktivasi & LOGSIG untuk \\
& & tiap layer \\
\hline
\end{tabular}

Parameter-paremater pada tabel 2. digunakan pada tiap arsitektur, untuk pengkodean program ANN backpropagation setiap arsitektur sama, hanya yang membedakan adalah arsitektur yang digunakan.

\section{Simulasi Model Matematika}

Berdasarkan Tabel 1 diatas, dilakukan pembelajaran tiap arsitektur, sehingga diperoleh arsitektur yang terbaik untuk selanjutnya dipilih dan dibuat model matematika. Berikut Hasil pembelajaran yang dilakukan. 
a. Lombok Tengah bagian Selatan

TABEL 3 .

HASIL PEMBELAJARAN TIAP ARSITEKTUR

\begin{tabular}{|c|c|c|c|c|c|c|c|}
\hline \multirow{2}{*}{$B_{0}^{N}$} & \multirow{2}{*}{ Parameter } & \multirow{2}{*}{ Nilai } & \multicolumn{5}{|c|}{ Arsitektur } \\
\hline & & & I & II & III & IV & $\mathrm{V}$ \\
\hline 1. & Maksimum Epoh & 5000 & 5000 & 5000 & 1258 & 857 & 510 \\
\hline 2. & Kinerja Tujuan / Toleransi Galat & $10^{-4}$ & $\begin{array}{c}0.00506 \\
574\end{array}$ & $\begin{array}{c}0.00019 \\
571\end{array}$ & $\begin{array}{c}9.99708 \mathrm{e}- \\
005\end{array}$ & $\begin{array}{c}9.99304 \mathrm{e}^{-} \\
005\end{array}$ & $\begin{array}{c}9.98933 \mathrm{e}- \\
\text { o05 }\end{array}$ \\
\hline 3. & Korelasi Kecocokan & 1 & 0.878 & 0.996 & 0.998 & 0.998 & 0.998 \\
\hline 4. & Maksimum Kenaikan Kinerja & 1.04 & 1.04 & 1.04 & 1.04 & 1.04 & 1.04 \\
\hline 5. & Learnig Rate & 0.01 & 0.01 & 0.01 & 0.01 & 0.01 & 0.01 \\
\hline 6. & Rasio Kenaikan Learning Rate & 1.05 & 1.05 & 1.05 & 1.05 & 1.05 & 1.05 \\
\hline 7. & Rasio Menurunkan Learning Rate & 0.7 & 0.7 & 0.7 & 0.7 & 0.7 & 0.7 \\
\hline 8. & Momentum & 0.9 & 0.9 & 0.9 & 0.9 & 0.9 & 0.9 \\
\hline
\end{tabular}

Berikut perbandingan grafik penuruanan error tiap arsistektur ANN dari awal training pada tiap epoch.

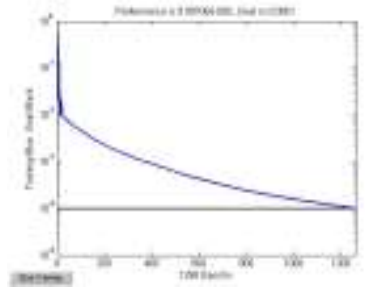

Gambar 3. Grafik Training Arsitektur III

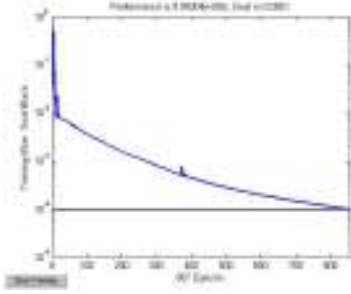

Gambar 4. Grafik Training Arsitektur IV

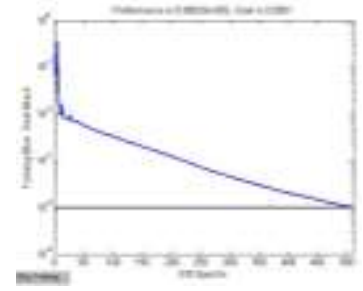

Gambar 5. Grafik

Training Arsitektur V

berikut grafik perbandiangan data pendekatan dan data target tiap arsitektur.

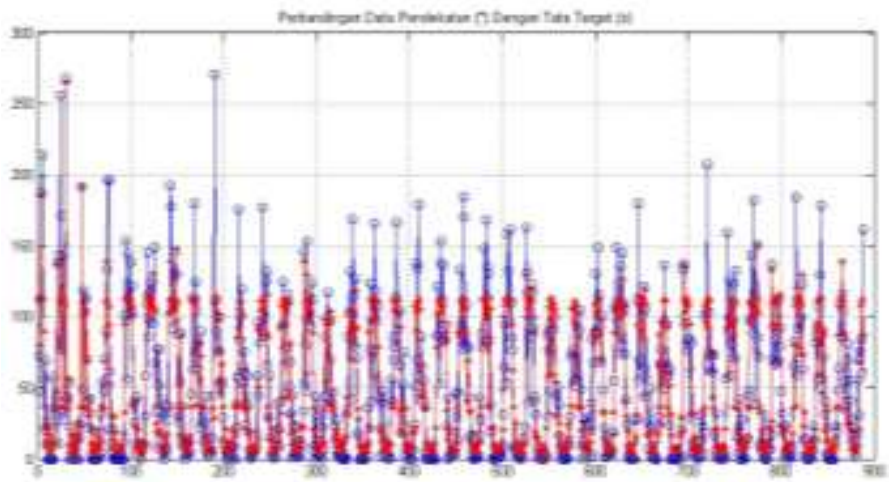

Gambar 6. Perbandingan Data Pendekatan $\left({ }^{*}\right)$ dengan Data Target (o) pada arsitektur I

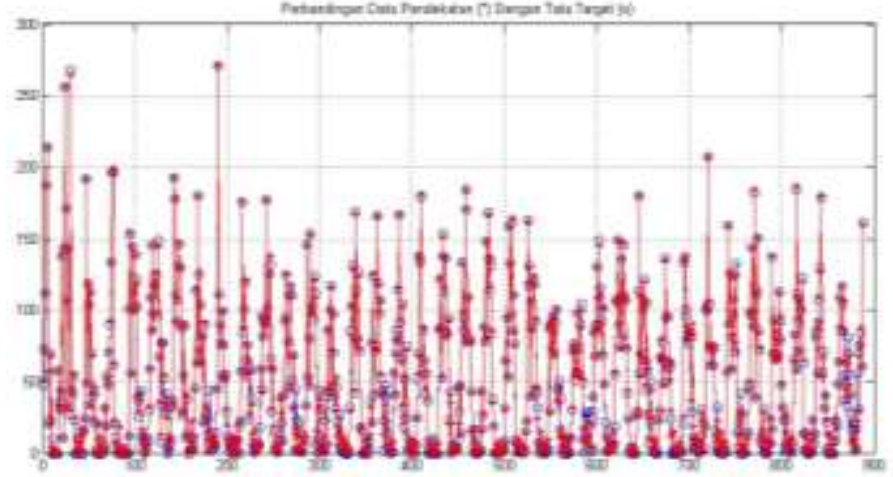

Gambar 7. Perbandingan Data Pendekatan (*) dengan Data Target (o) pada arsitektur II

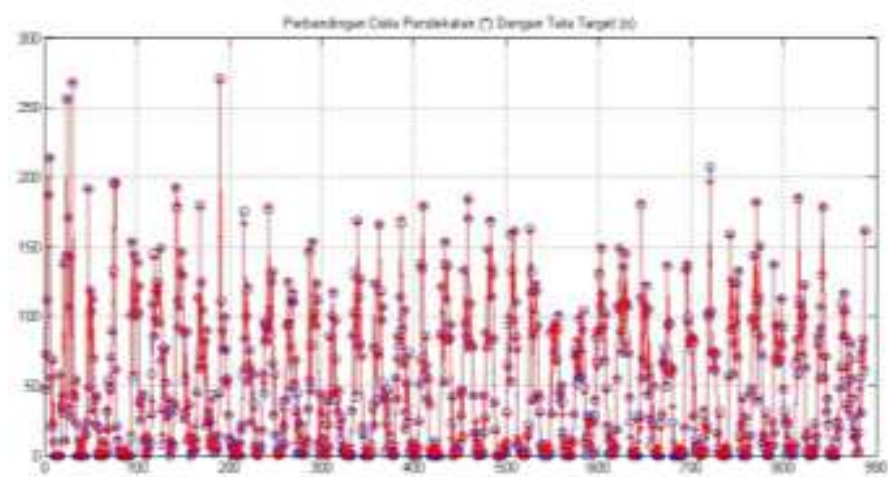

Gambar 8. Perbandingan Data Pendekatan $\left(^{*}\right)$ dengan Data Target (o) pada arsitektur III

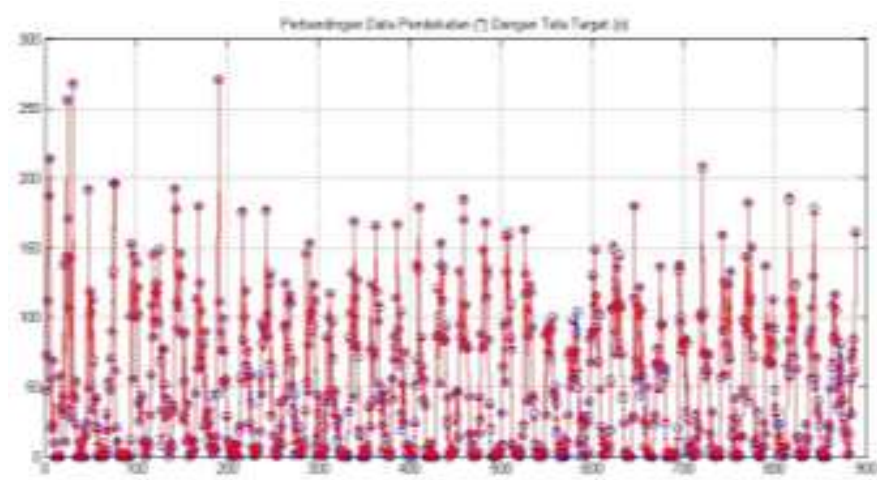

Gambar 9. Perbandingan Data Pendekatan (*) dengan Data Target (o) pada arsitektur IV 


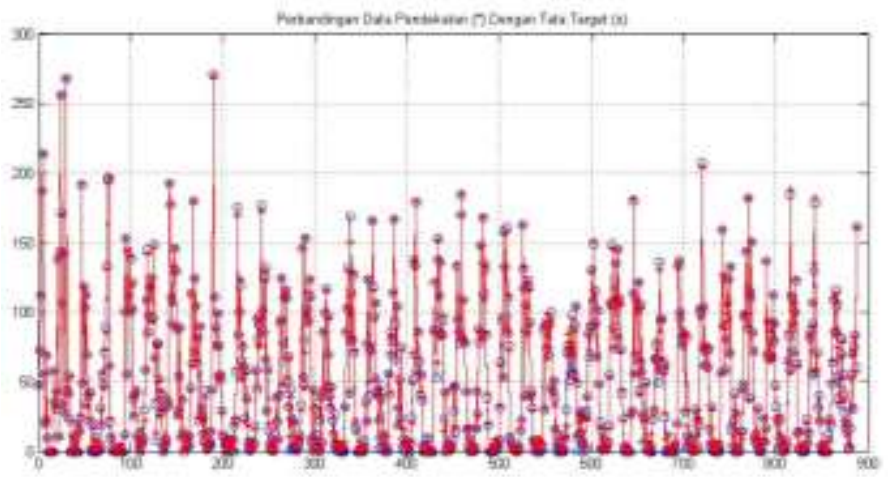

Gambar 10. Perbandingan Data Pendekatan $\left({ }^{*}\right)$ dengan Data Target (o) pada arsitektur V

Berdasarkan tabel 4.3, terlihat bahwa pada arsitektur $\mathrm{V}$ memiliki jumlah epoch terendah, dengan MSE sebesar 0.0000998 lebih kecil dari toleransi galat yang ditentukan yaitu 0.001 (Gambar 7), dan korelasi kecocokan output dan target sebesar 99\% (Gambar 12). Hasil ini menunjukkan bahwa arsitektur $V$ dapat mendekati data yang dipelajari (Gambar 17), sehingga arsitektur $\mathrm{V}$ dipilih untuk digunakan sebagai arsitektur dalam memprediksi curah hujan tahun 2011 di daerah Lombok Tengah bagian Selatan.

b. Lombok Timur bagian Selatan

TABEL 4

HASIL PEMBELAJARAN TIAP ARSITEKTUR

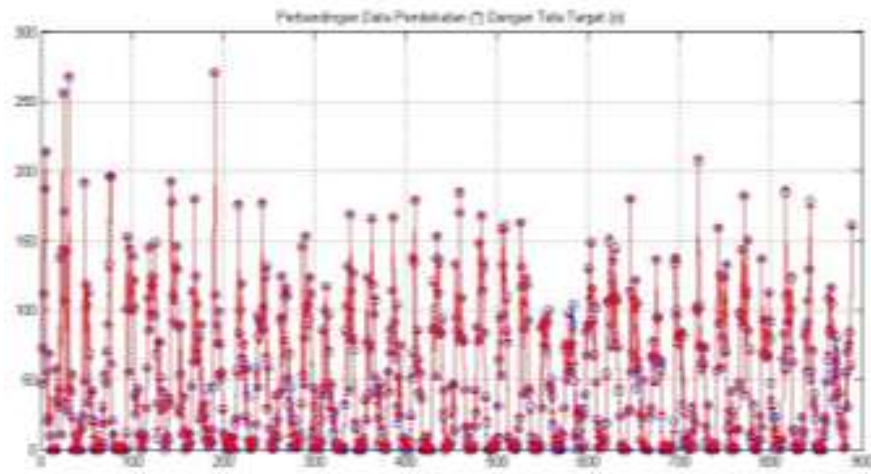

Gambar 12. Perbandingan Data Pendekatan $\left(^{*}\right)$ dengan Data Target (o) pada arsitektur IV

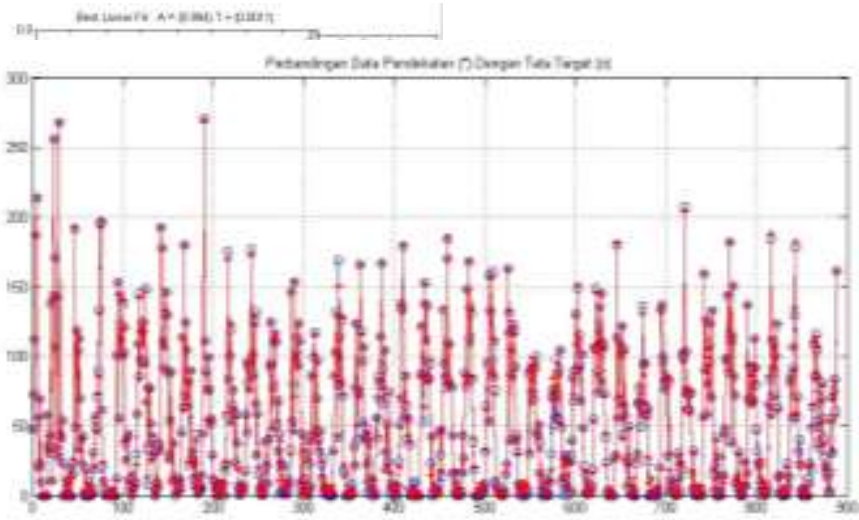

Gambar 13. Perbandingan Data Pendekatan (*) dengan Data Target (o) pada arsitektur V

\begin{tabular}{|c|l|c|c|c|c|c|c|}
\hline \multirow{2}{*}{ No } & \multicolumn{1}{|c|}{ Parameter } & \multirow{2}{*}{ Nilai } & \multicolumn{4}{c|}{ Arsitektur } \\
\cline { 4 - 9 } & & & I & II & III & IV & V \\
\hline 1. & Maksimum Epoh & 5000 & 5000 & 14358 & 1326 & 480 & 611 \\
\hline \multirow{2}{*}{2.} & Kinerja Tujuan / Toleransi Galat & \multirow{2}{*}{$10^{-4}$} & $\begin{array}{c}0.00421 \\
052\end{array}$ & $\begin{array}{c}9.99986 \mathrm{e} \\
-005\end{array}$ & $\begin{array}{c}9.98636 \mathrm{e} \\
-005\end{array}$ & $\begin{array}{c}9.97702 \mathrm{e} \\
-005\end{array}$ & $\begin{array}{c}9.98933 \mathrm{e} \\
-005\end{array}$ \\
\hline 3. & Korelasi Kecocokan & 1 & 0.889 & 0.998 & 0.998 & 0.998 & 0.998 \\
\hline 4. & Maksimum Kenaikan Kinerja & 1.04 & 1.04 & 1.04 & 1.04 & 1.04 & 1.04 \\
\hline 5. & Learnig Rate & 0.01 & 0.01 & 0.01 & 0.01 & 0.01 & 0.01 \\
\hline 6. & Rasio Kenaikan Learning Rate & 1.05 & 1.05 & 1.05 & 1.05 & 1.05 & 1.05 \\
\hline 7. & Rasio Menurunkan Learning Rate & 0.7 & 0.7 & 0.7 & 0.7 & 0.7 & 0.7 \\
\hline 8. & Momentum & 0.9 & 0.9 & 0.9 & 0.9 & 0.9 & 0.9 \\
\hline
\end{tabular}

berikut contoh grafik perbandiangan data pendekatan dan data target tiap arsitektur.

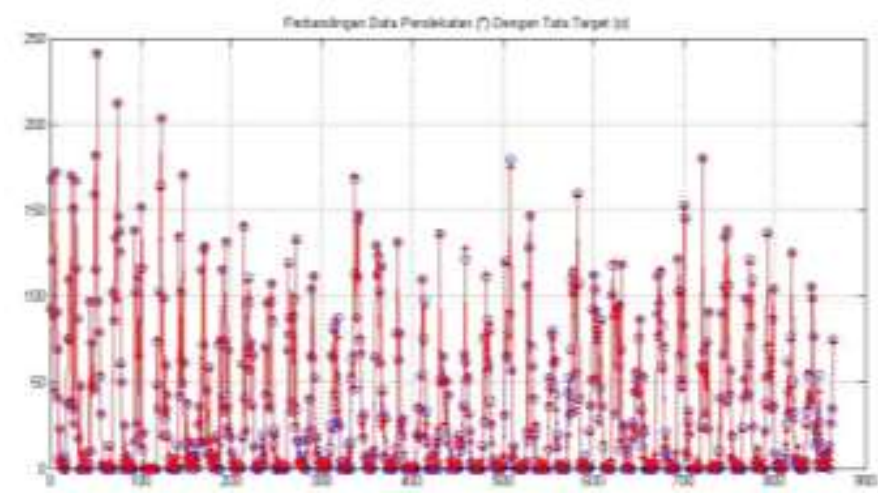

Gambar 11. Perbandingan Data Pendekatan $(*)$ dengan Data Target (o) pada arsitektur III
Berdasarkan Tabel 4. terlihat arsitektur IV memiliki jumlah epoch terendah, dengan MSE sebesar 0.0000997 lebih kecil dari toleransi galat yang ditentukan yaitu 0.001 (Gambar 21), dan korelasi kecocokan output dan target sebesar 99\% (Gambar 26). Hasil ini menunjukkan bahwa arsitektur IV dapat mendekati data yang dipelajari dengan baik (Gambar 31), sehingga arsitektur IV dipilih untuk digunakan sebagai arsitektur dalam memprediksi curah hujan tahun 2011 di daerah Lombok Timur bagian Selatan.

Untuk kontruksi model, diperoleh dari fungsi aktivasi yang digunakan dalam setiap layer pada proses prediksi pola curah hujan untuk tahun 2011. Fungsi aktivasi yang digunakan adalah fungsi sigmoid biner (logsig), dengan persamaan, $y=f(x)=\frac{1}{1+e^{-x}}$ dengan $x$ adalah data inputan. 
Pada arsitektur V dan IV yang terpilih terdapat 4 layer, yaitu 1 layer input 2 layer hidden dan 1 layer output, sehingga ada 4 fungsi aktivasi untuk tiap layernya. Sehingga persamaan yang digunakan dan merupakan model matematika pola curah hujan di daerah Lombok Tengah bagian Selatan dan Lombok Timur bagian Selatan dari fungsi aktivasi di setiap layernya, yaitu Persamaan pada layer I

$$
y 1=\frac{1}{1+e^{-\left(\left[\begin{array}{ll}
x & 1
\end{array}\right]^{*} W 1^{\prime}\right)}}
$$

Persamaa pada layer hidden 1

$$
y 2=\frac{1}{\left.\left.1+e^{-([y 1} 1\right]^{*} W 2^{\prime}\right)}
$$

Persamaan pada layer hidden 2

$$
y 3=\frac{1}{1+e^{-\left([y 21]^{*} W 3^{\prime}\right)}}
$$

Persamaa pada layer output

$$
y=\frac{1}{1+e^{-\left([y 31]^{*} W 4^{\prime}\right)}}
$$

dengan mensubsitusi persamaan (7), (8), dan (9) ke persamaan (10) kita memperoleh bentuk yang lebih simpel.

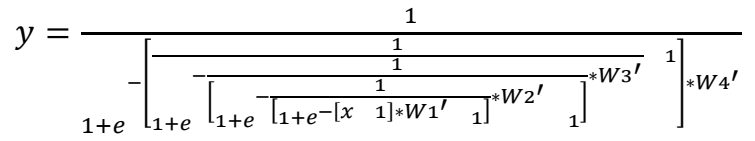

Diketahui logsig $=\frac{1}{1+e^{-x}}$ sehingga persamaan di atas dapat disederhanakan menjadi,

$$
y=\log \operatorname{sig}\left(\left[\operatorname { l o g } \operatorname { s i g } \left(\left[\operatorname { l o g } \operatorname { s i g } \left(\left[\log \operatorname{sig}\left(\left[\begin{array}{ll}
x & 1]
\end{array} * W 1^{\prime}\right) 1\right] *\right.\right.\right.\right.\right.\right.
$$$$
\left.\left.\left.\left.W 2^{\prime}\right) \text { 1] } * W 3^{\prime}\right) 1\right] * W 4^{\prime}\right)
$$

Keterangan :

$\mathrm{y}=$ nilai ouput

$\mathrm{x} \quad=$ matrik data inputan

W' ${ }^{\prime}=$ Matrik transpose dari data bobot dan bias pada layer 1

W2' = Matrik transpose dari data bobot dan bias pada layer 2

W3' = Matrik transpose dari data bobot dan bias pada layer 3

$\mathrm{W}_{4}^{\prime}=$ Matrik transpose dari data bobot dan bias pada layer 4

Nilai sinapsis (bobot) dari $W_{1}, W_{2}, W_{3}$ dan $W_{4}$ untuk arsitektur V dan IV berbeda, ini sesuai dengan data yang dipelajari. Untuk arsitektur $\mathrm{V}$ nilai sinapsis W1 adalah matrik berordo $120 \times 25$, W2 adalah matrik berordo $240 \times 121, W_{3}$ adalah matrik berordo 12 x 241 dan $W_{4}$ adalah matrik berordo $1 \mathrm{x}$ 13. Sedangkan untuk arsitektur IV nilai sinapsis $W 1$ adalah matrik berordo $363 \times 25$, W2 adalah matrik berordo $54 \times 364, W_{3}$ adalah matrik berordo $24 \times 55$ dan $W 4$ adalah matrik berordo $1 \times 25$.

\section{SIMPULAN DAN SARAN}

Model Matematika pola curah hujan untuk daerah Lombok Tengah bagian Selatan dan Lombok Timur bagian Selatan adalah : $y=\log \operatorname{sig}\left(\left[\log \operatorname{sig}\left(\left[\log \operatorname{sig}\left(\left[\log \operatorname{sig}\left(\left[\begin{array}{ll}x & 1]\end{array} * W 1^{\prime}\right) 1\right] *\right.\right.\right.\right.\right.\right.$ $\left.W 2^{\prime}\right)$ 1] $\left.\left.\left.* W 3^{\prime}\right) 1\right] * W 4^{\prime}\right)$

nilai sinapsis (bobot) dari $W_{1}, W_{2}, W_{3}$ dan $W_{4}$ untuk tiap daerah berbeda. Untuk model matematika daerah Lombok Tengah bagian Selatan nilai sinapsis $W_{1}$ adalah matrik berordo 120 × 25 , W2 adalah matrik berordo $240 \times 121, W 3$ adalah matrik berordo $12 \times 241$ dan $W 4$ adalah matrik berordo $1 \times 13$. Sedangkan untuk untuk model matematika daerah Lombok Timur bagian Selatan nilai sinapsis $W 1$ adalah matrik berordo $363 \mathrm{x}$ 25, W2 adalah matrik berordo $54 \times 364, W_{3}$ adalah matrik berordo $24 \times 55$ dan $W 4$ adalah matrik berordo 1 $\mathrm{x} 25$.

Berdasarkan hasil penelitian, maka saran yang dapat disampaikan adalah :

1. Transformasi data yang lain perlu dicoba untuk mendapatkan taburan data yang lebih stabil.

2. Modifikasi pada pelatihan standar backpropagation selain dengan menggunkan faktor momentum perlu dicoba untuk mempercepat iterasi seperti fungsi pelatihan yang digunakan maupun fungs aktivasi yang digunakan, sehingga diperoleh output jaringan dan hasil yang lebih baik.

\section{DAFTAR RUJUKAN}

[1] Aris Pramudia, Yonny Koesmaryono, Irsal Las, Tania June, I Wayan Astika, dan Eleonora Runtunuwu, "Pewilayahan Hujan dan Model Prediksi Curah Hujan Untuk Mendukung Analisis Ketersediaan dan Kerentanan Pangan di Sentra Produksi Padi”, Forum Pascasarjana, Vol 31, No. 2, h.132, April 2008.

[2] BISDA NTB, "Laporan Akhir Validasi data Hidrologi", Mataram, 2011.

[3] Sector Pertanian. Kajian Risiko dan Adaptasi Terhadap Perubahan Iklim Pulau Lombok Provinsi Nusa Tenggara Barat, Dinas Pertanian NTB, Mataram, 2011

[4] Soewarno, Hidrologi Jilid 1 (Aplikasi Metode Statistik untuk Analisis Data), Nova Bandung, 2008. 